\title{
ASKEL AIKUISOPISKELUUN
}

Miten pienentää etäisyyttä ja vähentää vierautta?

\begin{abstract}
Erås keino saada opiskeluun tottumattomia koulutukseen on jårjeståå koulutus osana työtå. Tållöin opiskelijoita karsivat aikaan, paikkaan ja rahoitukseen liittyvåt esteet ovat minimissäån. Tällaiset koulutuskokeilut ovat tuottaneet konkreettista hyötyå niin suoraan ammattitehtåvisså kuin vålillisesti kohonneena itsetuntona.
\end{abstract}

\begin{abstract}
Kirjoittajien mukaan on kuitenkin vaara, että työpaikkakoulutus lisåäntyy kaikille vapaasti tarjolla olevan koulutuksen kustannuksella. Aikuiskoulutuksen tulisikin kuvastaa elämån moninaisuutta, jolloin kaikki aikuisopintomuodot toisiaan tåydentåen tarjoavat kansalaisille rikkaamman elämån mahdollisuuksia. Tållöin eri opintomuotojen rajojen ylittåminen tulisi tehdå mahdollisimman helpoksi.
\end{abstract}

\begin{abstract}
Puolet ruotsalaisesta aikuisista osallistuu joka vuosi jonkinmuodoiseen aikuiskoulutukseen. Näin monien osallistuminen lienee ainutlaatuista maailmassa, vaikkakin useimpien opiskelu on aika pienimuotoista - opintokerho- tai paripäiväinen henkilöstökurssi (SCB 1988a). Runsaasta osallistumisesta huolimatta eri ryhmien välillä on kuitenkin melkoisia eroja. Hyvän koulutuspohjan entuudestaan omaaville koulutuksen toistuminen kuuluu nykyään asiaan, kun sen sijaan vähemmän koulutetut osallistuvat huomattavasti våhemmän tai tuskin lainkaan (Abrabamsson $\varepsilon \mathrm{Ru}$ benson, 1986).
\end{abstract}

Eräillä aikuiskoulutuksen aloilla eriarvoisuus on tavallista selvempi. Näin on erityisesti henkilöstökoulutuksessa, missä ryhmien erot ovat hyvin suuret. Harvat lyhyen koulutuksen läpikäyneet opiskelevat korkeakoulussa. Mitä korkeampi koulutustaso, sitä suurempi on pyrkimys myös omasäätöiseen opiskeluun, esimerkiksi kirjaston käyttöön (Borgström, 1988). Opintoliittojen opintokerhotoiminta, kansanopisto, työmarkkinakoulutus ja kunnallinen aikuiskoulutus tavoittavat ihmisiä tasapuolisesti, mutta myös niiden opiskelijoissa ovat heikosti koulutetut vähemmistönä (DcU, 1985:10). Aikuisten ja siirtolaisten perusopinnoissa (grundvux ja grund-sfi) on melko vähän niitä ihmisiä, joille perustaitojen puuttumisen takia kuuluisi etuoikeus. Epätasaisimmin on jakautunut niiden koulutusmuotojen käyttäminen, joihin yhteiskunta tukee ja joiden tavoitteena on luoda tasa-arvoa.

Tämän artikkelin tarkoituksena on pohtia, miten tasa-arvoa voidaan parantaa. On voitava luoda sellaiset opiskeluolosuhteet, että vähän koulutetut voidaan tavoittaa, mutta on myös saatava heidät suorittamaan opintonsa lop. puun. On tärkeää, että he voivat pitää oppimista mielekkäänä. Yksi perusongelma on se, että vähän koulutettujen ihmisten ja aikuiskoulutuksen välimatka on usein liian suuri. Tämä on artikkelimme teema. Aluksi muutamia argumentteja, miksi opiskeluun tottumattomien ihmisten kannattaa opiskella aikuisina. 


\section{Miksi opiskella aikuisena?}

On esitetty aiheellisia epäilyjä: Aikuisopiskelusta voi tulla pakko, samanlainen kuin aikanaan vastenmielisyyttä herättänyt koulu. $\mathrm{Ai}$ kuiskoulutus voi olla enemmän propagandaa kuin koulutusta tai sivistystä, aivan kuin koulu. tukseksi kutsuttujen toimintojen avulla yritettäisiin mainostaa yritystä. Vaikka aikuiskoulutus olisi "hyvää", ei ole sanottu, että kaikkien on opiskeltava. Ei aina tarvita organisoitua koulutusta, jotta ihmiset oppisivat, mitä on opittava. Se, että aikuisopiskelun merkitystä korostetaan, voi pikemminkin johtua kasvatta. jien ja kouluvälkkyjen maailmankuvasta kuin olla yleispätevä totuus.

Kuitenkin on myös monia hyvin maanläheisiä syitä siihen, että erityisesti vähän koulutusta saaneiden on syytä paneutua aikuisopintoihin. Niillä, jotka kansa- tai peruskoulussa eivät ole oppineet kunnollisesti lukemaan, kirjoitta. maan ja laskemaan, on elinikäinen vamma. Perusvalmiuksien puuttuminen rasittaa ihmistä sekä työelämässä että sen ulkopuolella. se vaatii häneltä pitkiä ja vaivalloisia kiertoteitä, jotta hän voisi välttää niitä toimintoja, joita ei hallitse. Ehkä vakavin seuraus on itseluotta. muksen puute, joka estää osallistumasta monenlaisin tilanteisiin: elämä typistää (Fransson, 1989, Fransson \& Karlsson, 1989).

Ne joilta puuttuu ammattikoulutus ja kunnollinen peruskoulutus, joutuvat sellaisiin töihin, joissa koulutusta ei vaadita. Usein nämä työt ovat huonosti palkattuja, niitä tehdään huonossa työympäristössä, ja niihin liittyy sairauksien tai tapaturmien vaara. Thång (1990) on osoittanut, että teollisuuden vähäarvoisim. pina pidetyt tehtävät katsotaan myös tervey. delle vaarallisiksi.

Vähän koulutetut ihmiset saavat henkilökoulutusta hyvin vähän, jos lainkaan, koska työtehtävät ahtaasti tulkittuna eivät sitä edelly. tä (Larsson ym, 1986), Landsorganisationen, 1989). Aikaa myöten tämä voi johtaa siihen, että työntekijän on vaikeaa selviytyä tehtävistään niiden muuttuessa tuntuvasti. Tilanne on samanlainen sekä työpaikalla että koko muuttuvilla työmarkkinoilla. Työelämä typistää.

"Tieto on valtaa" - tämän voimme konk reettisesti nähdä siinä, että hyvin koulutetut ovat sekä politiikassa että työelämässä vaikutusvaltaisimpia. "Kansalaisten aktiivisuutta mitattaessa voidaan useimmiten todeta, että se selvästi riippuu koulutuksesta... Hyvin koulutetut ottavat yhteyksiä, tekevät aloitteita, liittyvät järjestöihin, asioivat viranomaisten kanssa ja osallistuvat muilla tavoin paljon enemmän kuin huonosti koulutetut." (Petersson ym, 1989).

Vapaa sivistystyö on Ruotsissa niin kuin muissakin Pohjoismaissa avannut koulutusvaihtoehtoja, ja sen vaikutuksesta on saatu ta. vallisia kansanihmisiä mukaan politiikkaan sekä paikallisella että valtion tasolla. Vaikutuk. sensa on ollut sekä kansanopistoilla että opintoliitoilla. Vapaa sivistystyö on kouluttanut kansan syvien rivien ihmisiä perustelemaan vaatimuksiaan ja ajamaan asioitaan. (Arvidsson, 1985). On kysymys demokratiasta ja yhteiskunnan intressistä demokratian luomiseen.

Työpaikalla voi oppia, miten valtasuhteet toimivat. Jos ei tiedä, silloin on vailla valtaa eikä myöskään pysty vaikuttamaan asioihin. Koulutuksen avulla ihminen voi vahvistaa ase. maansa työyhteisössä.

Olemme tutkineet huonosti kulutettujen tilannetta useita vuosia, ja tulosten perusteella on mahdollista pohdiskella sitä, miten huo. nosti koulutettuja aikuisia voi vetää opiskele. maan. On enemmän kysymys käytännön joh. topäätöksistä kuin akateemisesta tutkimuk sesta. Tarkastelemme asiaa eri aikuiskulutus. muotojen kannalta, vaikka olemmekin parhaiten perehtyneet kunnalliseen aikuiskoulutukseen (komvux).

\section{Låheisyys ja etåisyys}

Aikuiskoulutus ja kouluttamattomat ihmiset ovat etäällä toisistaan. Asiaa voi tarkastella eri puolilta: Ehkä kysymyksessä on yksinkertaisesti maantieteellinen etäisyys. Myös sosiaalinen läheisyys tai etäisyys voi vaikuttaa siihen, samaistuuko joku aikuisopiskelijoihin. Kysymys voi myös olla kulttuurisesta läheisyydestä tai etäisyydestä. Kenties ihminen tuntee itsensä vieraaksi ja ulkopuoliseksi. Wahlgren (1986) luonnehtii huonosti koulutettuja juuri "koulutusta vieroksuviksi". Tämä vieraus on tunteenomainen vaikeus, vieraassa tilanteessa viihtyy huonosti.

Käsityksemme on, että koulutuksen tuominen lähelle on ratkaisevan tärkeää, jotta voitaisiin saavuttaa ne, jotka tähän asti ovat jättäytyneet ulkopuolelle. Ei pidä kuitenkaan unohtaa, että on sellaisiakin tilanteita, joissa läheisyys ei ole toivottavaa. Joskus voi olla tarvetta ottaa etäisyyttä omaan todellisuuteen - löytää erilaisia perspektiivejä kuin ne, jotka hallitsevat arkielämää. Suhteellisen riippumattomat aikuisopiskelumuodot, kuten kansanopisto ja komvux ovat muun muassa tämän takia 
erittäin tärkeitä. Ne antavat välimatkaa. Kun siis käsittelemme läheisyyttä positiivisena asiana, lukija pitäköön tämän huomautuksen mielessään. Läheisyys ei saa korvata vapautta ja riippumattomuutta.

Puhumme myös esteistä ja mahdollisuuksista. Nämä ovat erittäin käytännöllisiä puolia aikuisen osallistumisessa. Sillä, joka on käynyt pelkän peruskoulun, on erilaisia opiskelun esteitä. On myös mahdollisuuksia, jotka voi ottaa huomioon tai jättää ottamatta.

\section{Låheisyyden paradoksi}

Pääasiallinen pohdinnan aihe on siis se, miten etäisyyttä pienentämällä voidaan parantaa huonosti koulutettujen halukkuutta opintoihin. Siksi tuntuukin ehkä käsittämättömältä, että nämä ihmiset nykyään osallistuvat vähiten juuri sellaiseen koulutukseen, joka on heidän arkielämäänsä lähinnä, nimittäin henkilöstökoulutukseen.
Selitys on yksinkertainen. Suurimmalla osalla henkilöstökoulutuksesta on kokonaan eri tarkoitus kuin peruskoulutuksen parantaminen. Heikosti koulutetut tekevä usein sellaista työtä, joka ei vaadi paljon valmennusta. Muut suunnittelevat heidän työnsä ja johtavat sitä ja päättävät myös koulutukseen pääsystä. Viime kädessä asia riippuu siis siitä, miten nämä päättäjät suhtautuvat koulutukseen. Jos toiminnan perustana ei ole pyrkimys pitää heikosti koulutettujen puolta, silloin etäisyyden pienentämisellä ei liene merkitystä. Myöhem. min tulee puheeksi työpaikkakoulutus, ja siinä on aivan ratkaisevaa, millaisia tavoitteita sille asetetaan.

\section{Aikuiskoulutuksen soveltaminen opiskeluun tottumattomille}

Esittelemme aihetta seitsemän ulottuvuuden avulla: toinen pää edustaa aktiivisia ponnistuksia kouluttamattomien mukaansaamiseksi ja toinen pää passiivisempaa suhtautu. mista.

\section{HEIKOT TOIMENPITEET}

\author{
kaukana \\ ilmoittelu \\ puuttuvat
}

kurssimaksut, lainat

joustamattomat

satunnaiset

kiinteä, vailla

yhteyttä opiskelijan

elämään
PAIKKA

REKRYTOINTI

SILLAT OPISKELUIIN

RAHOITUS

AJAT

RYHMÄN KOOSTUMUS

KURSSIN SISÄLTÖ

\section{VOIMAKKAAT TOIMENPITEET}

Kun kuvion avulla on mahdollista analysoi$\mathrm{da}$, millä tavoin eri koulutusmuodoissa voidaan auttaa opiskeluun tottumattomia ihmisiä. Seuraavassa aisaa tarkastellaan yksityis. kohtaisemmin.

\section{Paikka}

Puhumme tässä paikasta maantieteellisessä mielessä. Eri aikuiskoulutuksen muodot ovat lähellä

yhteydenotto

opintojen ohjaus, kokeilu. mahdollisuuksia

ilmainen opetus, avustukset

joustavat

olemassa olevat henkilösuhteet

joustavasti sovellettu, elämäntilanteeseen mielekkäästi liittyvä

tältä kannalta hyvin erilaisia. On sellaista koulutusta, jota on tarjolla vain muutamissa paikoissa ja joka siksi on kaukana monien varsinaisesta elinympäristöstä, ja toisaalta on sellaista koulutusta, joka on sijoittunut tasaisesti eri puolille maata tai on keskellä ihmisen joka. päiväistä todellisuutta. Eri muotojen toimintaa voidaan kuitenkin kehitellä niin, että etäisyys pienenee. 
Toisessa ääripäässä on korkeakoulu; sinne on helppo päästä vain niiden, jotka asuvat jollakin suurella paikkakunnalla tai sen ympäris. tössä. Kansanopistoja on useita, ja monilla niistä on siteitä sijaintipaikkakuntaansa, erityisesti syrjäseudulla. Useimpien ihmisten on vaikea lähteä kansanopistoon. Lisäksi opistoilla on usein oma erikoisalansa ja ideologinen profiilinsa. Kunnallista aikuiskoulutusta on joka kunnassa, mutta se keskittyy yleensä kunnan keskustaan. Vain joissakin tapauksissa toimintaa on kunnan eri puolilla.

Suurten opintoliittojen toiminta on maantieteellisesti hyvin kattavaa - sitä on tarjolla sekä asutuskeskuksissa että syrjäseuduilla. Jäsenyhdistysten välityksellä toiminta usein ulottuu ihmisten arkiympäristöön, ja tällä asialla on maantieteellinenkin merkityksensä. Toinen aikuiskoulutuksen muoto, joka yleensä on maantieteellisesti lähellä, on henkilöstökoulutus. Mikäli henkilöstökoulutus on pakollista, sen sijoituksella ei ole merkitystä, mutta usein siihen rekrytoidaan paitsi komentamalla myös vapaaehtoisuuden pohjalta. Esimerkiksi hoitoalalla koulutuksen läheisyys tuntuu olevan merkittävä kiinnostuksen virittäjä (Larsson $\varepsilon$ Thång, 1985).

Henkilöstö- ja muun koulutuksen rajamailla on tilanteita, joissa maantieteellisellä välimatkalla saattaa olla merkitystä. Ajattelemme sellaista koulutusta, joka sijoittuu työpaikalle, mutta ei ole varsinaista henkilöstökoulutusta. Esimerkkinä voisi mainita kurssit, joita komvux järjestää aikuisten peruskoulutusta parantaakseen. Tällöin läheisyys on kahtalaista: paikallista (kurssi työpaikalla) ja sosiaalista (yhdessä työtoverin kanssa). Samanlainen tilanne on silloin, kun järjestetään kurssi oman työorganisaation muuttamiseksi, kuten Eriksson ja Holmer ovat osoittaneet (1990). Yhteys työpaikkaan ei ole vain paikallista läheisyyttä, vaan myös opiskelun sisällön edellytys: kysy. myksessä on oma työyhteisö.

\section{Rekrytointitapoja}

Rekrytoinnin ulottuvuuksien toinen pää merkitsee melko vähäistä ponnistelua, kuten esimerkiksi ilmoittelua. Toisessa päässä on erilaisia hakevan toiminnan muotoja. On ehkä olemassa muitakin erityisesti heikosti koulutettujen aikuisten tavoittamista varten suunniteltuja muotoja.

Suuri merkitys on informaation antajan ja vastaanottajan henkilökohtaisella kontaktilla. Hakeva toiminta on henkilökohtaisen yhteyden ottoa, jota kannattaa yrittää. Toinen ja vielä hyödyllisempi keino on keskustella sellais- ten henkilöiden kanssa, joilla on kokemuksia kysymyksessä olevasta kurssista. Kunnalliseen aikuiskoulutukseen rekrytointi käy enim. mäkseen "suusta suuhun" -menetelmällä (Fransson, 1990). Ne jotka ovat menestyksellisesti osallistuneet komvux-opintoihin, ovat konkreettinen esimerkki siitä, että aikuisopiskelu on realistinen mahdollisuus. Näin tuntuu olleen myös kotipalveluhenkilökunnan opintojen laita (Alexandersson, 1990).

Joskus on murrettava koulunvastainen kulttuuri (Ball, 1980), jossa heikosti koulutetut ovat eläneet tai yhä elävät. Ehkä se ei ole niin selvää Ruotsissa kuin Englannissa, mutta tietyssä määrin sitä kyllä ilmenee (Helmstad $\mathcal{E}$ Larsson, 1985). Koulu on oma maailmansa - sen ja huonosti koulutettujen ihmisten välillä on suuri sosiaalinen välimatka. Kun harjoitetaan hakevaa toimintaa, olisi tärkeää, että informaation antajiksi saataisiin niitä, joita pidetään "omina" ihmisinä, jotta vieraudentunne häviäisi.

Eräästä tutkimuksesta, joka koski apuhoitajien saamista mukaan opiskeluun (Larsson $\mathcal{E}$ Thång, 1985, Fransson $\mathcal{E}$ Larsson, 1989), käy ilmi erilaisia opiskelukiinnostuksen tyyppejä. Oli niitä, jotka tekivät pitkäjänteisiä suunnitelmia niin määrätietoisesti, että he vain tarvitsivat tietoa oikeasta koulutustiestä.

Toisille taas opiskelu oli ratkaisu vaikeaan elämäntilanteeseen. "Kriisissä" olevat ihmiset tarvitsevat aktiivisempaa apua löytääkseen oikean opiskelutien. Tätä apua on annettava silloin, kun hätä on suurin. Opiskelu tuo ratkaisun vain siinä tapauksessa, että se on mahdol. lista juuri oikeaan aikaan. Jatkuva opiskelijaksi otto ja muut joustavat järjestelyt helpottavat tällaisten ihmisten hakeutumista opiskelemaan. Tärkeätä on myös aktiivinen ohjaus.

Lisäksi oli vielä ryhmä, jolla voitaisiin sanoa olevan "piilevää opiskeluhalua". Tähän kuulu. vat ihmiset paneutuivat opiskeluun perinpohjaisesti, mutta vain jos saivat tehdä sen omalla työpaikallaan ja muutenkin edullisin ehdoin. Myös muu lähimiljöö kuin työpaikka voi sopia tälle ryhmälle. Jotta siihen kuuluvat tavoitettaisiin, tarvitaan tavanomaista "kokonaisvaltaisempaa" rekrytointia. On tärkeää, että opiskelu saa ympäristön vahvan tuen ja että jokapäiväisistä tavoista ei tarvitse luopua. Todennäköisesti tästä ryhmästä löytyvät aikuisopiskelun tärkeimmät ja ensisijaisimmat kohderyhmät.

\section{Sillat opiskeluun}

Yksi tapa pienentää etäisyyttä tasokkaisiin 
ja perinpohjaisiin opintoihin on järjestää lyhyitä kursseja, joilla opiskeluun tottumaton voi muutaman viikon aikana kokea, millaista opiskelu on. Valmistava kurssi voi antaa tilaisuu. den kokeilla eri aineiden opiskelua ja miettiä, mikä kiinnostaa. Se voi myös antaa osanotta. jille tilaisuuden tutustua itseensä ja opiskelu. edellytyksiinsä.

Yhä useammilla paikkakunnilla järjestää ABF (Arbetarnas Bildningsförbund) yleisaineiden kursseja päivän viikossa läpi vuoden. Tämä tapahtuu ns. ABF-kouluissa. Osanotta. jat saavat yleensä opintotukea lyhytkestoista opiskelua varten, ja kurssin laajuus määräytyy tämän tuen sääntöjen mukaisesti. Usein osanottajat rekrytoidaan saman yrityksen piiristä tai samalta ammattialalta, ja siksi heillä on paljon yhteistä. Södertäljessä ABF-kurssien osanottajat voivat kurssin jälkeen jatkaa komvuxin kursseilla ja suorittaa peruskoulun.

Samantapaisista vapaan sivistystyön ja komvuxin yhteistyön muodoista keskustellaan nyt eri tahoilla, ja kehitys saattaa johtaa siihen, että opintokerhosta tulee ensimmäinen askel pidempään opiskelujaksoon; tätähän suunniteltiin 70-luvun puolivälissä, jolloin myös aikuisopintotuki luotiin.

Opintoihin valmentavia, noin kuukauden pituisia kursseja pidetään useissa kunnissa, usein eri koululaitosten yhteistyönä, mutta yleensä vain komvuxin alaisena. Jos tällaisten opintojen rahoitus on onnistuttu ratkaisemaan, kuten esimerkiksi Gävlessä, niistä on tullut hyvin merkittävä väylä kohti laajempia opintoja. Vuonna 1987/88 osallistui komvu. xin järjestämiin opintovalmennuskursseihin Gävlessä yhteensä 105 henkeä, ja näistä 70 jatkoi sitten seuraavaan vaiheeseen, etappiin 1. Yli puolet etapin 1. opiskelijoista Gävlessä tulee valmennuskurssin kautta. Muita siltoja opiskeluun voivat olla vanhemmille järjestetyt kurssit, esimerkiksi yläasteen matematiikkaa kerran viikossa yhden lukukauden aikana. Tällaisille kursseille ilmoittautumisen motiivina on usein halu auttaa omaa lasta koululäksyis. sä. Tuloksena on usein se, että vanhempi itse innostuu opiskelemaan.

\section{Rahoitus}

Ei ole epäilystäkään, että taloudelliset tekijät vaikuttavat ratkaisevasti (Lundquist, 1989). Rahoituksen toinen ääripää merkitsee, että ihmisten on pakko ottaa velkaa, usein koko elämänsä ajaksi; yleensä on kysymys rahoituk. sesta, josta $2 / 3$ on lainaa. Heikosti koulutettuihin tämä koskee eniten, koska heidän tulonsa edellyttävät itse asiassa, että opintojen avulla saadaan niin paljon lisätuloja, että ne vastaa. vat lainan määrä. Näiden ryhmien opintojen rahoitus on usein epärealistisella pohjalla.

Toisessa ääripäässä on koulutus, johon osallistuva saa täyden palkan; usein kysymyksessä on henkilöstökoulutus. Lähellä tätä on työvoimakoulutus, johon annetaan opintoavustusta, sekä eräät aikuisten peruskoulutuksen (grundvux) muodot. Vähän huonommassa asemassa ovat ne, jotka saavat erityistä aikuisopintotukea, mistä lainan osuus on noin 1/3. Merkillinen piirre opintojen rahoituksessa on, että eri opiskelijoilla on niin erilaiset edut. Komvuxin kurssilla voi samassa luokkahuoneessa olla opiskelijoita melkein kaikista edellä mainituista ryhmistä. Jos saataisiin aikaan parempi tuki niille, jotka opiskelevat työaikana, ja kannustusavustus muille, taloudelliset opiskelun esteet voitaisiin poistaa grundvux. opiskelusta.

Enimmälle osalle Ruotsin aikuiskoulutusta on yhteistä se, että kurssimaksut ovat pienet tai niitä ei ole lainkaan. Komvux ja kansanopisto eivät ota kurssimaksua. Opintokerhojen osallistumismaksut ovat aikaisemmin olleet varsin pienet, mutta viime aikoina ne ovat tuntuvasti nousseet. Pienituloisille merkitsevät taloudelliset ehdot huomattavasti enemmän kuin muille. Jos maksut ovat kalliit, opiskelijain rekrytointi vinoutuu. Laaja-alaiseen, päätoimiseen opiskeluun hakeutuminen rajoittuu pääasiallisesti niihin mahdollisuuksiin, jotka eivät tuo mukanaan liian suurta velkataakkaa. Työhön liittyvään opiskeluun on mahdollista saada osallistumaan aikuisia, mikäli he voivat saada opiskeluajalta täyttä palkkaa (Fransson, 1989).

Sillä, miten paljon opintoavustusta ja erityis. tä aikuisopintorahaa on saatavissa, on suuri vaikutus heikosti koulutettujen ihmisten pää. toimiseen, ehkä myös osa-aikaiseen opiskeluun. Keskushallinnon poliittisilla päätöksillä on siis ratkaisevan tärkeä vaikutus siihen, miten monet aikuiset lähtevät paikkaamaan heikkoa koulupohjaansa. Mikään muu yksityinen toimenpide ei merkitse rekrytoinnin kan. nalta yhtä paljon.

Aikuisen tilanteesta katsottuna opiskelun vaikutus perheen talouteen saattaa ratkaista, katsooko hän, että hänellä on varaa opiskella. Tässä eri ryhmät ovat erilaisessa asemassa. Ehkä perheen taloudellinen tilanne on yksi syy siihen, että naiset ovat halukkaampia aikuisopiskeluun. Monille heikosti koulutetuille miehille, jotka ovat kokopäivätyössä, opinnot saattavat merkitä suurta taloudellista menetys. 
tä. Sen sijaan osapäiväistä, matalapalkkaista työtä tekevän naisen opiskelulla ei ole niin suurta taloudellista vaikutusta; usein aikuisopintotuki jopa kattaa tulonmenetyksen ihan kokonaan (Lundquist, 1989). Ehkä tämä jonkin verran kompensoi työelämässä vallitsevaa tasa-arvon puutetta. Mutta se ei ratkaise niiden ongelmia, joilla ei ole varaa opiskella aikuisina, vain koska ovat päätoimisessa työssä.

\section{Ajat}

Kurssien järjestäjät näyttävät lähtevän siitä, että ihmisillä on säännölliset työajat ja vapaat illat ja pyhäpäivät. Siksi kurssit ajoitetaan kiinteästi tietyiksi viikonpäiviksi ja kellonajoiksi. On kuitenkin isoja ryhmiä, erityisesti hoito- ja palvelualoilla, mutta myös teollisuudessa, joille tällainen ajoitus ei sovi. Siksi heidän on vaikeaa käyttää hyväkseen tarjolla olevia mah. dollisuuksia, elleivät he taloudellisista syistä voi ottaa opintovapaata. Monet tekevät vuorotyötä, toiset työskentelevät tiiviisti pitkiä jaksoja epämukavina aikoina ja saavat sen jälkeen pitkän vapaan. Joillakin aloilla työnsaanti riip. puu sesongista. Poikkeavina aikoina työskentelevien lukumäärä lisääntyy koko ajan. Jos ei aikuisopintoja organisoida sillä tavalla, että työelämän edellytykset otetaan huomioon, suuri joukko jää niistä osattomaksi. Kaksi komvuxista otettua esimerkkiä osoittaa, miten poikkeukselliset työajat voidaan ottaa huomioon:

Sundsvallissa järjestetään 1. etapin englan. nin ja matematiikan kursseja aikataulua joustaen niin, että vuorotyötä tekevien on helpom. pi osallistua. Opetus toistuu kolmena vaih. toehtoisena aikana: aamupäivällä, iltapäivällä ja illalla. Osanottajat voivat vapaasti valita, ja opettaja on kaikissa tilanteissa sama.

Simrishamnin komvuxin esimerkki osoittaa, että koulutuksen rytmi voidaan mukauttaa työelämän sesonkirytmiin. Maanviljelys ja turismi ovat täällä vallitsevat elinkeinot. Siksi työnsaanti vaihtelee eri vuodenaikoina, kiireinen kausi on syyspuolella. Jos kurssit aloitetaan elo-syyskuussa, kuten komvuxin kurssit tavallisesti, ei ehkä tavoiteta koulutusta tarvitsevaa heikosti koulutettua ryhmää. Ongelma on ratkaistu aloittamalla kurssit vasta marraskuussa. Osanottajat voivat liittyä mukaan orientaatiokurssiin vielä viitenä vuodenlopun viikkona. Vasta tammikuussa, kun maanvilje. lyksessä ja turismissa on hyvin hiljaista, opetus alkaa toden teolla. Tiedotus ja rekrytointi tapahtuvat pitkin vuotta, pääasiallisesti kevätkaudella.
Yksi tapa ottaa työaika huomioon on ajoitta opetus työajan alkamisen tai päättymisen mu. kaan. Näin on menetelty uudistusrahastojen rahoittamia kursseja järjestettäessä. Tämä kuitenkin edellyttää, että osanottajilla on samat työajat ja että työpaikat ovat lähellä toisiaan.

Ongelma voidaan ohittaa myös etäopintojen avulla, jolloin kukin opiskelija voi opiskella itselleen sopivana aikana. Valtion kouluista saadut kokemukset osoittavat, että tällainen opiskelu vaatii jonkin verran opiskelutottumusta. Siksipä etäopetus ei ratkaisekaan huonosti koulutettujen ongelmia.

\section{Ryhmån kokoonpano}

Kansansivistyksen alkuaikoina olivat opintoryhmät enimmäkseen jo muutenkin olemassa olevia ryhmiä (Ambjörnsson, 1988). Opiskelu oli osa jonkin kansanliikkeen toimintaa., Amerikkalaisessa ikuiskasvatuksessa tällaisesta käytetään nimitystä "community-based adult education". Termiä "community" on vaikea kääntää, mutta kysymys on ihmisistä, jotka kuuluvat jonkinlaiseen tunnistettavaan yhteisöön, uskonnolliseen, kulttuuriseen tai harrastusryhmään. Ehkä tarkoitetaan samalla alueella asuvia ihmisiä, joilla siksi on yhteisiä kokemuksia ja intressejä. Näiden pohjalta suunnitellaan koulutus. Näiden ihmisten kou. lutustarve, opiskeluedellytykset ja yleinen elämäntilanne määräävät koulutuksen suunnan ja luonteen.

Tällainen näkemys poikkeaa huomattavasti siitå, mikä meillä on nykyään tavallinen. Meillä yleensä on lähtökohtana koulutusta järjestävä taho, olipa kysymyksessä komvux tai kansansivistys. Rekrytointi kohdistuu kaikkiin, jotka täyttävät muodolliset kelpoisuusvaatimukset, mikäli sellaisia on. Ilmoittelu ja muu informaatio osoitetaan suurelle yleisölle.

Jos jotakin kohderyhmää priorisoidaan, esimerkiksi kunnallisessa aikuiskoulutuksessa, silloin mahdollisten osanottajien ainoa yhteinen tekijä on yhteinen koulutustarve, mutta ei kulttuurin luoma yhteys. Hyvin harvoin koulutusta suunnitellaan erityisesti sellaisille ihmisille, joilla on yhteisiä kokemuksia ja jo ennes. tään jonkinlainen luonnollinen yhteys. Poikkeuksena ovat ne kurssit, joilla opintoliittojen jäsenjårjestöt kouluttavat jäseniään. Toinen poikkeus ovat henkilöstökurssit, jotka on suunnattu jollekin työntekijäryhmälle, tai am. matillinen koulutus, jota annetaan työpaikalla.

Tästä seuraa, että opintoryhmät muodostuvat kokoonpanoltaan sattumanvaraisiksi, toi- 
sin sanoen niihin tulee ihmisiä, jotka ovat sattuneet ilmoittautumaan samaan aikaan. Mahdollisia yhteisiä intressejä ja kokemuksia voidaan yrittää löytää vasta, kun ryhmä on perus. tettu. Sisällön ja työmuotojen suhteuttaminen näihin yhteisiin kokemuksiin käy mahdolliseksi vasta sitten, kun kurssi on jo menossa. Hel. posti käy niin, että opettaja ja etukäteen tehty kurssiohjelma dominoivat ja kurssista tulee koulumainen.

Toiseksi, se joka haluaa osallistua aikuisopiskeluun, joutuu normaalitapauksessa liittymåän tuntemattomien ihmisten joukkoon, jonka intresseistå ja opiskeluedellytyksistä hä. nellä ei ole tietoa. Sille, joka etsii uusia haasteita ja uusia kontakteja, tämå voi olla jännittä. vää. Mutta sille, jonka itseluottamus on heikko ja joka epäilee mahdollisuuksiaan, askel tuntemattomaan voi tuntua niin uhkaavalta, että mieluummin luopuu koko kurssista.

Se, joka aikoo omistautua vaativiin opintoihin, joutuu paljastamaan ympäristölleen, ettå hänellä on kunnianhimo ja uskoa omiin kykyihinsä. Silloin on helposti kiitollinen saalis Janten lain kannattajille. Yritys muuttaa elämäntilannettaan aikuisena opiskelemalla vaatii määrätietoisuutta ja voimaa - jos on työryh. mässään tai toveripiirissään ainoa, joka näin tekee. Se, jolla opiskelunhalu on pillevä, antaa halunsa myös jäädä piiloon.

Muutamat ruotsalaiset yritykset ovat kunnallisen aikuiskoulutuksen kanssa yhteistyös. sä hylänneet passiivisen mallin ja systemaattisesti suunnanneet rekrytointinsa jo olemassa oleviin luonnollisiin ryhmiin.

Kokemukset osoittavat selvästi, että monet jotka muuten tuskin koskaan olisivat tulleet ilmoittautuneeksi kelpoisuutta antavaan koulutukseen, nyt lähtevät mukaan, kun saavat opiskella yhdessä työtoveriensa kanssa, varsinkin jos opetus suoranaisesti liittyy työpaik. kaan.

Yksi esimerkki (Fransson, 1989) on Volvo Lastvagnar AB Göteborgissa. Uudistusrahastojen varoin aloitettiin useita isoja projekteja. Lajissaan huomattavin on "tehostettu perus. koulutus" ruotsissa, matematiikassa ja englannissa. Yli puolet niistä 30 miljoonasta, jotka tämä göteborgilainen tehdas sijoittaa työntekijöiden koulutukseen, käytetään tämän projek. tiin.

Tehostetun peruskoulutuksen kohderyh. mänä ovat kaikki ne työntekijät, jotka ovat käyneet pelkän kansakoulun tai 9-vuotisen peruskoulun. VLAB:n 4220 työntekijästä 1400 kuuluu tähän ryhmään, näistä 777:llä oli vain kansakoulu.
Yksi yrityksen toimintamuodoista, "konstruktion och utveckling", valittiin pilottikokeiluksi. Siihen kuului tuhat työntekijää, joista 154:llä oli enintään peruskoulun tiedot. Päätettiin, että kaikkien kohderyhmään kuuluvien luona vierailisi yksi yrityksen ja yksi ammattiyhdistyksen edustaja, jotka kyselisivät asia. nomaisen kiinnostusta peruskoulutasoiseen ruotsin, englannin tai matematiikan opiskeluun. Kaikkiaan 97 henkilöä ilmoitti olevansa kiinnostunut, ja heidät kutsuttiin saamaan tarkempaa informaatiota kursseista ja osallistumaan intressiaineittensa testiin. Testien perus. teella sitten osanottajat jaettiin pohjatietojensa mukaisiin ryhmiin.

Koulutus alkoi tammikuussa 1987. Osanottajat jakaantuivat kuudelle kurssille: 1. ja 2. etapin tasoista ruotsia, englantia ja matematiikkaa sekä ATK:n perusopetusta ja tekstinkäsittelyä. Koulutus siis tavoitti enemmän kuin puolet tämän osaston kohderyhmästä. Opetusta annettiin palkallisena työaikana puoli päivää kerrallaan kaksi kertaa viikossa kahden lukukauden ajan. Läksyt oli luettava vapaa-aikana. Kurssipaikka oli kävelyetäisyyden päässä työpaikalta.

Tätå ensimmäistä kurssijaksoa seurasivat uudet kurssit, joilla oli osanottajia muista osas. toista. Kahden ja puolen vuoden kuluttua oli 230 henkilöä osallistunut yhteen tai useam. paan kurssiin. Harvat olivat jättäneet opiskelun kesken; syynä oli useimmiten se, että läksyjen luku oli vienyt odottamattoman paljon aikaa. Arvioidaan, että kaikkiaan 20 prosenttia koh. deryhmästä tulee osallistumaan tehostettuun peruskoulutukseen. Luku on korkea. erityisesti kun otetaan huomioon, että nykyään hyvin harvat ammattityötä tekevät miehet käyttävät hyväkseen opintovapaan mahdollisuutta parantaakseen perustaitojaan ruotsissa, matematiikassa ja englannissa.

Mahdollisuus opiskella työtovereiden kanssa yhdessä työpaikan läheisyydessä merkitsi monien opiskelun esteiden poisraivaamista samalla kertaa. Oli mahdollista tavoitta paljon suurempi osa kohderyhmästä, kuin jos olisi käytetty tavanomaista rekrytointia. Ensimmäisen arvioinnin näistä kursseista ovat esittäneet Jacobsson ja Jansson (1989), Esimerkki osoittaa piilevän opiskeluhalun laajuuden.

\section{Kurssin sisålto̊}

Listamme viimeinen ulottuvuus on opintojen sisältö ja sen liittyminen osanottajien kokemuksiin ja elämäntilanteisiin. Vaikka kokemuksista lähteminen onkin aikuiskoulutuksen keskeinen ihanne, nåyttå olevan harvinaista, 
että sisältö mukautetaan ryhmän tarpeisiin. Sisällön mukauttamista voi tarkastella kahdelta puolelta: ensiksi, miten sisältö vaikuttaa rekry. tointiin, ja toiseksi, miten sisältöä kehitellään kurssin jo alettua.

Ensimmäisestä näkökohdasta voidaan sa. noa, että heikosti koulutettujen rekrytointi riippuu suuresti siitä, mitä konkreettista hyötyä nämä katsovat opiskelun tuovan. Monet tutkimukset osoittavat tämän (esimerkiksi Larsson ym, 1986), vaikkakin Thångin artikkelin osittain viittaa toiseen suuntaan. Monista tutkimuksista käy ilmi, että heikosti koulutetut jo melko nuorena katsovat olevansa "valmiita"; on mainittu iät 30 ja 35 vuota. Tämä merkitsee, että ihmiset katsovat olevansa opiskelumahdollisuuksien ulkopuolella. Aikuiskoulutus ei tunnu mielekkäältä, ellei siitä ole käytännön hyötyä ja ellei itsekään ole kovin nuori. Heikosti koulutetut ovat melkein aina sellaises. sa tilanteessa, missä käytännön hyötyä on vaikea nähdä.

Yleissivistyksen katsotaan kuuluvan niille, jotka ovat luomassa uraa, jotka haluavat "tulla joksikin", nuorille ihmisille. Ammattiin liittyvä koulutus on niitä varten, jotka tarvitsevat tietoa tai taitoa johonkin tiettyyn työtehtävään. Ammattiyhdistyskoulutus on tarkoitettu niille, jotka ovat luottamustehtävissä tai aikovat sellaisiin.

Usein myös koulutuksesta vastaavilla on samanlaisia ajatuksia - koulutuksen on oltava kannattavaa tai resursseja on käytettävä siellä, missä välttämättä tarvitaan. Tästä syntyy epäilyttävä yhteisymmärrys kaikkien osapuolten kesken, ja heikosti koulutetut jäävät koulutuksen ulkopuolelle, minkä takia he sitten eivät saa parempia (terveellisimpiä, mielekkäämpiä jne.) töitä. Näin joudutaan noidankehään.

Yksi tapa opiskeluun tottumattomien mukaansaamiseksi on järjestää koulutusta työn osana niin, että sen tarkoituksena on työpaikan muuttaminen. Eriksson ja Holmer (1990) kertovat tällaisesta koulutuksesta. He yrittävät saada erään teollisuuslaitoksen työntekijät perehtymään työn muuttumiseen ja sillä tavalla itse tulemaan aktiivisiksi työpaikkansa muutoksen ajajiksi.

Tanskassa on käynnissä tutkimus (Rosenk. vist, 1989), joka osoittaa, että ammattiaineita ja yleisaineita on vaikea integroida, mutta kurssiohjelma, joka sisältää molempia, suo osanottajille mahdollisuuden kehittää itseluottamustaan, ja sillä on siksi tärkeä merkitys. Ammattitaidot antavat suoranaisesti käyttökelpoista käytännön kompetenssia ja yleissivistävät vahvistavat yksilön itsetuntoa kansalaisena.
Petersson (1990) tekee selkoa kokeilusta, jonka tarkoituksena on tehostaa sekä ammattiyhdistysopintoja että henkilöstö- ja ammattikoulutusta. Projektin ovat tuottaneet yhteisvoimin ammattiyhdistyksen opinto-organisaatio ja asianomainen yritys.

Näissä kolmessa tapauksessa yritetään ottaa huomioon sekä ammatilliset näkökohdat että kansalaistaidot. Opinnot ovat konkreettisesti hyödyllisiä, mutta antavat myös sellaista tietoa, jolla on jokin muu merkitys kuin am. matillinen hyöty. Lisäksi tulee parantunut itsetunto, joka myös merkitsee paljon yhteiskunnan jäsenen kannalta. Työpaikalla järjestettävään koulutukseen liittyy kuitenkin vakava ky. symys: Kuka päättääå sisällöstä? Miten vapaa ja riippumaton koulutus voidaan yhdistää työpaikkakoulutukseen? Tämä edellyttää sitoutumatonta kurssinjärjestäjää, mutta myös riippumattomuutta korostavaa asennetta.

\section{Opintojen valitsemisen vapaudesta}

Olemme aikaisemmin kirjoittaneet taloudellisista esteistä, joita on opintosuunnitelmien toteuttamisen tiellä. Oma lukunsa ovat opiskelijaksi valitsemista koskevat säännöt. Luulisi, että vapaa pääsy olisi sopiva heikosti koulutetuille ja että rajoitukset estäisivät heitä. Osittain onkin näin, mutta todellisuus on silti monimutkainen.

Yleiset kirjastot ja opintoliitot ovat niitä opiskelumuotoja, jotka ovat ilman rajoituksia kaikille avoinna. On myös välimuotoja, joissa joillekin koulutuslinjoille on pääsyvaatimuksia, mutta kaikille ei. Monille komvuxin kursseille on käytännössä vapaa pääsy, mutta joissakin tapauksissa asia ei ole näin. Toisaalta on olemassa myös tavoite, jonka mukaan etusija on annettava vähiten koulutusta saaneille. Tätä ajatusta noudattavat myös eräät budjettiehdotukset ja erityisesti opintotuen myöntämistä koskevat säännöt. Opintotukisäännöt vaikuttanevat myös kansanopiston opiskelijoihin, vaikka mitään erityisiä etuoikeuksia ei olekaan, lu. kuunottamatta niitä, jotka liittyvät aikuiskoulutuksen yleisiin päämääriin. Kansanopistoissa on yleisen opiskelukelpoisuuden vaatimus, mutta ne jotka sen täyttävät, voivat käytännössä ilman muuta osallistua erillisiin kursseihin.

Kaikkein tiukimmin säännelty on pääsy niihin opintoihin, joihin valitaan yksilöllisesti. Näin on henkilöstökoulutuksessa ja työmark. kinakoulutuksessa. Niitä eivät yksilöt voi vapaasti valita, vaan joku virkamies ratkaisee, mikä kullekin sopii. Toisinaan tarjotaan vapaa. 
takin valintaa, mutta nämä tapaukset ovat poikkeuksia. Niinpä kansalaiset näissä tilanteissa ovat riippuvaisia toisistaan ja tämä on demokratian kannalta ongelma.

Henkilöstökoulutuksen valintaperusteet ovat vähiten koulutetuille erityisen epäedulliset. Asian taustalla lienee eräänlainen tehoajattelu (kannattavuus), jonka mukaan työnantaja panostaa eniten taitoa vaativien töiden tekijöihin. Tärkeä tähän asiaan vaikuttava tekijä ovat teollisuuden tuotantolaskelmat; näiden mittaukset osoittavat, ettå koulutus vähentää tuotantoa, koskapa kurssilla olevat ihmiset eivät silloin osallistu tuotantoon. Tämä koskee erityisesti työkollektiiveja. Muilla aikuiskoulutuksen aloilla on sellaisia tasa-arvopäämääriä, joita henkilökoulutuksessa ei ole. Ammattiyhdistysten vaatimukset voivat jossain määrin vaikuttaa, mutta yleensä tuntuu siltä, että työnantajan näkemys koulutuksesta ei tee oikeutta heikosti koulutetuille.

On olemassa ilmeinen vaara, että työpaik. kakoulutus lisääntyy kaikille vapaasti tarjolla olevan koulutuksen kustannuksella. Tavallinen syy, miksi ihmiset hakeutuvat opiskelemaan, on halu päästä pois työstä, joka tuntuu tarkoituksettomalta tai epäterveelliseltä. Silloin opiskelumahdollisuuksien pitäisi olla avoinna kenelle tahansa. Jos on olemassa mahdollisuus työpaikan vaihtoon koulutusta hankkimalla, silloin myös työnantajiin kohdistuu paine huonojen työolojen parantamiseksi niin, että he voivat pitää työntekijänsä. Jos ei ole mahdollista "paeta" huonosta työpaikasta, silloin ihmisen on pakko hyväksyä olosuhteet, jotka eivăt ole hyväksyttäviä. Vaihtoehto huonosta työpai. kasta poislähtöön on, että työntekijä yrittää muuttaa tilannettaan omin päin.

\section{Pitkån aikavålin nåkőaloja}

Aikuiskoulutusta koskevassa keskustelussa pohditaan usein rekrytointi- ja opetuskysymyksiä yksittäisten kurssinjärjestäjien kannalta. Sen sijaan saattaa unohtua pitempi pers. pektiivi, jossa kaikki aikuisopintomuodot nähdään kansalaisille tarjottavina rikkaamman elämän mahdollisuuksina. Sivistyskäsitystä pidetään usein itsestään selvänä, ja monessa ta. pauksessa se on ahdas ja yksipuolinen. Meidän mielestämme aikuiskoulutuksen pitää ku. vastaa elämän moninaisuutta; tämä olisi aina. kin ihanne. Kun opiskeluun tottumattomat ihmiset ovat innostuneet opintoihin, perusta on luotu. He ovat ehkä saaneet uusia valmiuksia ja uutta itseluottamusta. Jotta kehitys jatkuisi, tietoja on pidettävä yllä ja kartutettava, on omaksuttava uusia tottumuksia - yksinkertai- sesti ehkä vain alettava lukea sanomalehteä uudella tavalla. Voi myös aueta avarampia kulttuuri- ja sivistyskontakteja.

Koulutuksesta vastuussa olevat voivat tehdä oman osuutensa auttamalla osanottajia muuntamaan opintoharrastuksensa elämäntavoiksi. He voivat ohjata näitä yhteyteen vapaan sivis. tystyön ja kirjaston kanssa. Miten opiskelu järjestetään niin, että sen apuna on luonnollista käyttää hyväkseen paikkakunnan kirjastoa? Miten järjestetään teatteri- tai elokuvakäynti niin, että se tukee opiskelua? On monia tapoja, joilla eri opintomuotojen rajojen ylittämistä voidaan helpottaa. Mitä opintoliitot tekevät houkutellakseen osanottajia ryhtymään laajaalaisempaan opiskeluun kansanopistossa tai komvuxin piirissä? Mitä komvux tekee, jotta opiskelijoiden harrastus jatkuisi opintokerhois. sa?

On oltava hyvää tahtoa, on luovuttava kilpailumielestä ja sen sijaan katsottava opiskelijan parasta ja etäällä olevia päämääriä.

\section{LÄHTEET}

Abrahamsson, K. \& Rubenson, K., 1986. (red.) Den nya utbildningsklyftan - 90-talets utmaning, SÖ: Liber Utbildningsförlag.

Alexandersson, C. 1990. Utbildning och professionalisering. I: Kollegiet för vuxenubildning, Göteborgs universitet: Studiesteg för vuxna. Publikation frăn Institutet för pedagogik, Göteborgs universitet 1990:03.

Ambjörnsson, R. 1988. Den skötsamme arbetaren. Malmö: Carlssons Bokförlag.

Arvidsson, L. 1985. Folkbildning i rörelse. Pedagogisk syn i folkbildning inom svensk arbetarrörelse och frikyrkorörelse under 1900-talet - en jämförelse. Malmö: Liber förlag.

Ball, S. 1980. Beachside Comprehensive. Cambridge: University Press.

Borgström, L. 1988. Vuxnas kunskapssökande - en studie av självstyrt lärande. Stockholm: Brevskolan. DsU 1985:10. Vuxenutbildning. 1970-talets reformer - en utvärdering. Stockholm: Utbildningsdepartement.

Eriksson, K. \& Holmer, J. 1990. Studier som stöd för arbetet. I: Kollegiet för vuxenutbildning, Göteborgs universitet: Studiesteg för vuxna. Publication frăn Institutet för pedagogik, Göteborgs universitet 1990:03.

Fransson, A. 1990. Anpassning av rekrytering, studievägledning och undervisning till prioriterade grupper. En studie av 10 komvuxenheter. (Manus).

Fransson, A. Rekrytering av kortutbildade vuxna. Erfarenheter från Sverige. Föredrag vid konferensen Nye veje for voksenuddannelsen I Norden, Reykjavik 25. august 1989. Institutionen för pedagogik, Göteborgs universitet. Stencil. 
Fransson, A. \& Larsson, S. 1989. Who takes the second chance, Report nr 1989:02 from the Department of Education and Educational research, University of Göteborg.

Helmstad, G. \& Larsson, S. 1985. Föreställningar om utbildning, Intervjuer med lagerarbetare, Rapport nr 1985:09, Institutionen för pedagogik, Göteborgs universitet.

Jacobsson, G. \& Jansson, S. 1989. Förnyelsefonder vid Volvo Lastvagnar $A B$ i Göteborg. Göteborgs Skolförvaltning.

Keen, K. 1989. (samtal).

Larsson, S. \& Alexandersson, C. \& Helmstad, G. \& Thång, P-O. 1986. Arbetsupplevelse och utbildningssyn hos icke facklärda, Göteborg: Acta Universitatis Gothoburgensis.

Larsson, S. \& Thång, P-O. 1985. Arbetets betydelse och utbildningens funktion. En empirisk studie av sjukvårdsbiträdens syn på arbete och utbildning. Rapport nr 1985:03, Institutionen för pedagogik, Göteborgs universitet.

Larsson, S. 1989. Vuxnas möte med komvux, (manus).

Larsson, S. \& Fransson, A. \& Alexandersson, C. 1990. 124 lärarens syn på sin undervisning i komvux. (manus).
Landsorganisationen 1989. Personalutbildning överväganden och förslag, LO.

Lundquist, O. 1989. Studiestöd för vuxna. Utveckling, utnyttjande, utfall. Acta Universitatis Gothobugensis.

Petersson, B. 1990. Metallindustriarbetare - lärande och utbildning, Göteborgs universitet: Studiesteg för vuxna. Publikation från Institutet för pedagogik. Göteborgs universitet 1990:03.

Petersson, O. \& Westholm, A. \& Blomberg, G. 1989. Medborgarnas makt, Stockholm: Carssons.

Rosenvist, G. 1989. Kompetensutveckling vid integrerad utbildning. (manus).

SCB(a). 1988. Personalutbildning. Våren 1987. Bakgrundmaterial om vuxenutbildning. 1988:1.

SCB(b). 1988. Vuxenutbildning 1986, regional spridning, Bakgrunds-material om vuxenutbildning, 1988:3.

Wahlgren, B. 1986. De uddannelsefremmede, Erfaringer fra försögs- og udviklingsarbejde med prioriterede grupper $\mathrm{i}$ voksenundervisningen og folkeoplysningen, Udviklingscenter for folkeoplysning og voksenundervisning, Köbenhavn. 


\section{AIKUISKASVATUS \\ The Finnish Journal of Adult Education \\ Vol. 11, 2/91 \\ ISSN 0358.6197 \\ Summary}

Fransson Anders \& Larsson Staffan 1991. Askel aikuisopiskeluun - Miten pienentåä etäisyyttä ja vähentää vierautta.

- Artikkelissa käsitelläån aikuisopiskelun esteitä läheisyyden ja etäisyyden näkökulmasta. Läheisyys - ja etäisyystekijöitå ovat mm. opiskelu. paikka, ajankohta, rahoitus, opiskeluun rekry. toinnin keinot sekä opetuksen sisällön jousta. vuus. Eräs tie opiskeluesteiden vähentämiseen olisi se, että aikuiskoulutuksen järjestäjät luopuisivat keskinåisestä kilpailusta ja ryhtyisivät rekry. toinnissaan katsomaan opiskelijain parasta ja etãållä olevia päåmäååriå.

Aikuiskasvatus 11,2.
Fransson Anders E Larsson Staffan 1991. A step towards adult education -. How to reduce the distance and strangeness.

- The article deals with obstacles to adult education from the point of view of distance and familiarity. Familiarity and distance factors inclu. de place of study, time, funding, recruitment me. ans and the flexibility of the contents of the inst. ruction given. - ne way of reducing study obstac. les would be for the organizers of adult education to discard mutual competition and give conside. ration to the interests of the student in their rec. ruitment policies and the goals that are somew.. here in the distance.

Aikuiskasvatus 11,2. 